Abstracta Iranica Abstracta Iranica

Revue bibliographique pour le domaine irano-aryen

Volume 30 | 2010

Comptes rendus des publications de 2007

\title{
Shi'ite Pilgrimage to the Sacred 'Atabāt. Kyoto, Kyoto University Press, 2007, iv + 422 p. [in Japanese]
}

\section{Akihiko Yamaguchi}

\section{(2) OpenEdition}

1 Journals

\section{Édition électronique}

URL : http://journals.openedition.org/abstractairanica/37913

DOI : 10.4000/abstractairanica.37913

ISSN : 1961-960X

Éditeur :

CNRS (UMR 7528 Mondes iraniens et indiens), Éditions de l'IFRI

\section{Édition imprimée}

Date de publication : 8 avril 2010

ISSN : 0240-8910

\section{Référence électronique}

Akihiko Yamaguchi, « Shi'te Pilgrimage to the Sacred 'Atabāt. Kyoto, Kyoto University Press, 2007, iv + 422 p. [in Japanese] », Abstracta Iranica [En ligne], Volume 30 | 2010, document 221, mis en ligne le 08 avril 2010, consulté le 26 septembre 2020. URL : http://journals.openedition.org/abstractairanica/ 37913 ; DOI : https://doi.org/10.4000/abstractairanica.37913

Ce document a été généré automatiquement le 26 septembre 2020.

Tous droits réservés 


\title{
Shi'ite Pilgrimage to the Sacred 'Atabāt. Kyoto, Kyoto University Press, 2007, iv +422 p. [in Japanese]
}

\author{
Akihiko Yamaguchi
}

1 This pioneering work, a revised edition of the author's doctoral thesis, investigates extensively a well-known but little studied phenomenon of the flourishing pilgrimage of Shiite Iranians to the 'Atabāt during the 19th century. According to the author, approximately 100,000 Shiite Iranians annually flocked to the holy shrines in the second half of the century. What made so many people cross the border to visit the sacred sites under Ottoman control at that time? By what route and means of transport did they go there? How did they spend their time in the holy places? How did the Qajar and Ottoman authorities deal with this huge wave of pilgrims? In order to investigate thoroughly this significant event in Shiite history, Morikawa addresses these fundamental questions by using a plethora of edited and inedited historical materials, such as travelogues of pilgrims and Ottoman and Qajar official documents.

After the introduction, the work is divided into ten chapters: Chapter I. Shi'i Doctrine and Ziyāra Pilgrimage to the Toms of the Imams; Chapter II. The Historical Setting: Rise and Decline of Pilgrimage to the 'Atabāt; Chapter III. Journey to the 'Atabāt; Chapter IV. At the Sacred Sites in Iraq; Chapter V. Pilgrimage of the Dead: Shi'i Culture of 'Transfer Corpses'; Chapter VI. 'Atabāt Pilgrimage as a Diplomatic Problem; Chapter VII. Pilgrims and Security: Risking Lives and Property, Chapter VIII. Constraints of 'Modernization'; Chapter IX. Shi'i Pilgrims and Iraq under the Ottomans; Chapter X. The 'Atabāt Pilgrimage in Iranian Society. Appendix contains brief descriptions of the main Persian travelogues used in the work, a detailed itinerary of the authors of these travel accounts, a Japanese translation of treaties and diplomatic documents concerning the pilgrimage, a Japanese translation of the seventh chapter of Jāmi'i-yi 'Abbāsī, and a list of the tombs of saints located in the province of Baghdad.

The greatest merit of the work lies in the fact that it has opened up a new field of the study of the 'Atabāt pilgrimage, one of the most important rituals for the Shiite 
Muslims. In spite of its importance, the theme has not been fully studied until now. Addressing broad-ranging questions about the pilgrimage, we can safely say, the present work has offered a framework of reference for future study of the matter.

4 In addition, the work offers an unique and therefore fascinating perspective: the author does not strictly limit her scope of interest to the religious aspects of the pilgrimage, but she pays close attention also to its 'secular' sides, in particular, its aspect of being a 'travel abroad'. At the time when the means of transport were limited, the round trip to the 'Atabāt was a difficult entreprise which required even more time and energy than the sojourn there itself. Even though the 'Atabāt was situated much nearer than Sacred Mecca for an Iranian pilgrim, it was nevertheless located in a foreign country controlled by the Sunni Ottoman dynasty, and pilgrims were forced to go there by foot. Thus, the journey across the border to the holy sites posed numerous problems to pilgrims. Based on this standpoint, the author carefully examines religious, political, diplomatic and social contexts within which the pilgrimage was accomplished.

INDEX

Thèmes : 7. Islam

\section{AUTEURS}

AKIHIKO YAMAGUCHI

University of Sacred Heart - Tokyo 